\title{
Determination of Efficient and Inefficient Stocks with the Capital Asset Price Model (CAPM) Method
}

\author{
I Wayan Sunarya
}

STMIK STIKOM Indonesia

iwayansunarya@gmail.com

\begin{tabular}{ll}
\hline \multicolumn{2}{l}{ ARTICLEDETAILS } \\
\hline History \\
Received & $:$ February \\
RevisedFormat & $:$ March \\
Accepted & $:$ April \\
\hline
\end{tabular}

Keywords :

capital asset pricing model, beta, efficient stock

\begin{abstract}
S
Stock selection by an investor needs to be done with a variety of existing analysis for example the application of the Capital Asset Price Model. In the Composite Stock Index known as LQ45 shares. LQ45 shares have a unique characteristic that is their shares are liquid, meaning their shares are favored by investors because the average has very good fundamentals. For this reason, in this study the selected stocks, LQ45 shares, are used to determine which shares are worth buying and which shares are not worth buying. Because the names of companies incorporated in LQ45 continue to change from year to year, in this study using a sample of LQ45 company data, amounting to 30 companies where the company was chosen because from 2017 to 2019, the company remains in the LQ45 stock group. For research data sources sourced from Yahoo Finance and take a variety of reading sources both through journals and online media. As for determining efficient and inefficient stocks lies in the value of the individual Expected Return or often abbreviated as [E (Ri)]. If the Individual Expected Return is greater than the value of the Individual Return (Ri) then the shares are in the efficient stock.
\end{abstract}

\section{INTRODUCTION}

The Indonesian financial system is more and more affected by the Indonesian home market in very proper situation in sustaining the economy. Indonesia is a united states that has the fourth biggest population, the 1/3 largest democratic power, and for the degree of Southeast Asia the Indonesian economic system is at the $13^{\text {th }}$ degree in the world so that this causes local and foreign traders to be involved in investing in Indonesia in the hope of getting a return on investment already implanted. A united states can be said to be advanced if the country's financial boom has developed rapidly. Owned shares will furnish benefits for shareholders who are regularly recognized through the charge return acquired in accordance with the stage of hazard that can be borne by way of traders (Susanti \& Putra, 2019). In addition to being influenced via the domestic market, Indonesia's economic system is additionally affected with the aid of the stock market, recognised as the Composite Stock Price Index (CSPI). The percentage alternate in the IHSG has an evaluation in calculating the return cost of shares on the Indonesia Stock Exchange (Adisetiawan, 2017).

In inspecting the advantages and risks that will be confronted by investors, the CAPM can be used as an analysis to describe the relationship between returns and risks contained in a stock traded on the Indonesia Stock Exchange (Liani, 2017). When the market is in balance, the danger evaluation of stocks will be more influenced by means of the Beta indicator $(\beta)$ with the capital price asset model (CPAM). CPAM consists of Risk market (Rm), Risk free $(\mathrm{Rf})$, beta $(\beta)$ and Expected Return [E (Ri)]. In addition, the CAPM evaluation is used to determine the forecasting of hazard correlations with expected returns and decide the price of company assets (Ditha Indah et al., 2019). The assumption contained 
in the CAPM is that the capital market is efficient so that all belongings owned through agencies that are categorised into LQ45 on the Indonesia Stock Exchange will be perfectly divided and at the time of sale and purchase, the company's shares are sold. At CAPM, market portfolios are very influential the place traders will normally diversify and select an most useful portfolio based totally on know how of the risks and returns provided by way of these shares. A stock will have an overvalued and overrated state, where these two conditions provide a signal that the shares that are grouped in LQ45 are in an environment friendly or inefficient situation (Riska et al., 2014).

When the shares are overvalued, the shares are ready to be sold. On the opposite when the shares are undervalued, the shares are well worth buying. This is completed by traders by means of capacity of undervalued shares which are efficient shares and selling shares that are overvalued or inefficient. The shares on the Indonesia Stock Exchange are LQ45 kind shares and normal shares, for LQ45 shares amounting to 45 organizations that have high capital and liquidity. From the lookup of 45 corporations categorized as LQ45 shares, solely 30 companies had been selected to be sampled in this study. A pattern of 30 corporations used to be chosen because these shares continually fall into the LQ45 category from 2017-2019. The LQ45 team company facts protected in this study are:

Table 1. LQ45 Company Sample Data from 2017-2019

\begin{tabular}{cll}
\hline No. & Stock Code & \multicolumn{1}{c}{ Company Name } \\
\hline 1. & ADRO & PT. Adaro Energy Tbk \\
\hline 2. & AKRA & PT. AKR Corporindo Tbk \\
\hline 3. & ANTM & PT. Aneka Tambang Tbk \\
\hline 4. & ASII & PT. Astra International Tbk \\
\hline 5. & BBCA & PT. Bank Central Asia Tbk \\
\hline 6. & BBNI & PT. Bank Negara Indonesia Tbk \\
\hline 7. & BBRI & PT. Bank Rakyat Indonesia Tbk \\
\hline 8. & BBTN & PT. Bank Tabungan Negara Tbk \\
\hline 9. & BMRI & PT. Bank Mandiri Tbk \\
\hline 10. & BRPT & PT. Barito Pacific Tbk \\
\hline 11. & BSDE & PT. Bumi Serpong Damai Tbk \\
\hline 12. & EXCL & PT. XL Axiata Tbk. \\
\hline 13. & GGRM & PT. Gudang Garam Tbk. \\
\hline 14. & HMSP & PT. Hanjaya Mandala Sampoerna Tbk \\
\hline 15. & ICBP & PT. Indofood CBP Sukses Makmur Tbk \\
\hline 16. & INCO & PT. Vale Indonesia Tbk \\
\hline 17. & INDF & PT. Indofood Sukses Makmur Tbk \\
\hline 18. & INTP & PT. Indocement Tunggal Prakarsa Tbk \\
\hline 19. & JSMR & PT. Jasa Marga (Persero) Tbk \\
\hline 20. & KLBF & PT. Kalbe Farma Tbk. \\
\hline 21. & LPPF & PT. Matahari Department Store Tbk \\
\hline 22. & MNCN & PT. Media Nusantara Citra Tbk \\
\hline 23. & PGAS & PT. Perusahaan Gas Negara Tbk \\
\hline 24. & PTBA & PT. Bukit Asam Tbk \\
\hline 26. & PTPP & PCMA PP (Persero) Tbk \\
\hline 27. & SMGR & PT. Surya Citra Media Tbk \\
\hline & & \\
\hline PT. Semen Indonesia (Persero) Tbk \\
\hline INA
\end{tabular}




\begin{tabular}{cll}
\hline 28. & SRIL & PT. Sri Rejeki Isman Tbk \\
\hline 29. & TLKM & PT. Telekomunikasi Indonesia Tbk \\
\hline 30. & UNTR & PT. United Tractors Tbk \\
\hline
\end{tabular}

Source: Yahoo Finance, 2020

Furthermore, for the common closing of the stock price from 2017-2019 as follows:

Table 2. Closing Stock Price of LQ45 Company Stock Prices from 2017-2019

\begin{tabular}{|c|c|c|c|c|}
\hline \multirow{2}{*}{ No. } & \multirow{2}{*}{$\begin{array}{l}\text { Stock Code } \\
\text { ADRO }\end{array}$} & \multirow{2}{*}{$\begin{array}{l}\text { Company Name } \\
\text { PT. Adaro Energy Tbk }\end{array}$} & \multicolumn{2}{|c|}{$\begin{array}{c}\text { Average } \\
\text { Stock Price }\end{array}$} \\
\hline & & & $\mathrm{Rp}$ & 1.634 \\
\hline 2 & AKRA & PT. AKR Corporindo Tbk & $\mathrm{Rp}$ & 1.634 \\
\hline 3 & ANTM & PT. Aneka Tambang Tbk & $\mathrm{Rp}$ & 1.634 \\
\hline 4 & ASII & PT. Astra International Tbk & $\mathrm{Rp}$ & 7.679 \\
\hline 5 & $\mathrm{BBCA}$ & PT. Bank Central Asia Tbk & $\mathrm{Rp}$ & 24.001 \\
\hline 6 & BBNI & PT. Bank Negara Indonesia Tbk & $\mathrm{Rp}$ & 7.927 \\
\hline 7 & BBRI & PT. Bank Rakyat Indonesia Tbk & $\mathrm{Rp}$ & 3.476 \\
\hline 8 & BBTN & PT. Bank Tabungan Negara Tbk & $\mathrm{Rp}$ & 2.625 \\
\hline 9 & BMRI & PT. Bank Mandiri Tbk & $\mathrm{Rp}$ & 7.067 \\
\hline 10 & BRPT & PT. Barito Pacific Tbk & $\mathrm{Rp}$ & 856 \\
\hline 11 & BSDE & PT. Bumi Serpong Damai Tbk & $\mathrm{Rp}$ & 1.551 \\
\hline 12 & EXCL & PT. XL Axiata Tbk. & $\mathrm{Rp}$ & 2.928 \\
\hline 13 & GGRM & PT. Gudang Garam Tbk. & $\mathrm{Rp}$ & 72.294 \\
\hline 14 & HMSP & PT. Hanjaya Mandala Sampoerna Tbk & $\mathrm{Rp}$ & 3.609 \\
\hline 15 & ICBP & PT. Indofood CBP Sukses Makmur Tbk & $\mathrm{Rp}$ & 9.434 \\
\hline 16 & INCO & PT. Vale Indonesia Tbk & $\mathrm{Rp}$ & 3.117 \\
\hline 17 & INDF & PT. Indofood Sukses Makmur Tbk & $\mathrm{Rp}$ & 7.447 \\
\hline 18 & INTP & PT. Indocement Tunggal Prakarsa Tbk & $\mathrm{Rp}$ & 18.834 \\
\hline 19 & JSMR & PT. Jasa Marga (Persero) Tbk & $\mathrm{Rp}$ & 5.189 \\
\hline 20 & KLBF & PT. Kalbe Farma Tbk. & $\mathrm{Rp}$ & 1.532 \\
\hline 21 & LPPF & PT. Matahari Department Store Tbk & $\mathrm{Rp}$ & 8.193 \\
\hline 22 & MNCN & PT. Media Nusantara Citra Tbk & $\mathrm{Rp}$ & 1.284 \\
\hline 23 & PGAS & PT. Perusahaan Gas Negara Tbk & $\mathrm{Rp}$ & 2.189 \\
\hline 24 & PTBA & PT. Bukit Asam Tbk & $\mathrm{Rp}$ & 3.103 \\
\hline 25 & PTPP & PT. PP (Persero) Tbk & $\mathrm{Rp}$ & 2.384 \\
\hline 26 & SCMA & PT. Surya Citra Media Tbk & $\mathrm{Rp}$ & 2.092 \\
\hline 27 & SMGR & PT. Semen Indonesia (Persero) Tbk & $\mathrm{Rp}$ & 10.655 \\
\hline 28 & SRIL & PT. Sri Rejeki Isman Tbk & $\mathrm{Rp}$ & 335 \\
\hline 29 & TLKM & PT. Telekomunikasi Indonesia Tbk & $\mathrm{Rp}$ & 4.029 \\
\hline 30 & UNTR & PT. United Tractors Tbk & $\mathrm{Rp}$ & 9.332 \\
\hline
\end{tabular}

Source : Data Processed, 2020

As for numerous studies conducted by means of Wildan Deny et al. (2015) related to the use of CPAM analysis in figuring out environment friendly or inefficient stocks, where the outcomes generated from three sample groups were 21 shares categorised as efficient and 16 shares classified as inefficient shares. In addition, the consequences of lookup conducted by means of Riska et al. (2014) states that there are six businesses that can be grouped 
into environment friendly shares and one inefficient stock. Besides that, a find out about carried out via Susanti \& Putra (2019) noted that there had been 10 LQ45 shares which had been categorised as environment friendly shares while the ultimate 10 company share of LQ45 had been categorized as inefficient shares.

\section{RESEARCH METHOD}

The records analysis approach uses descriptive quantitative analysis. The populace consists of the LQ45 Index from 2017-2019. For secondary data in this find out about obtained from quite a number parties such as Library Research and Online Research are additionally utilized in this study. While the sampling technique uses purposive sampling method. According to Susanti \& Putra (2019) states the price of return of character shares or regularly abbreviated as $\mathrm{Ri}$ (Return Individual) is an analysis to calculate the price of return of a stock in a positive period. As for how to calculate the charge of return of character shares, namely:

$$
\mathrm{Ri}=\frac{P_{t}-\left(P_{t-1}\right)}{P_{t-1}}
$$

With Ri is Rate of return of man or woman shares, and Pt is duration share rate $\mathrm{t}$ and then Pt1 is Share charge length $\mathrm{t}-1$. For data evaluation of market returns used are sourced from the Composite Stock Price Index. The Composite Stock Price Index is one of the analyzes consisting of normal inventory rate data which has a very influential energy in monetary occasions that take place in Indonesia (Ni Wayan Sri \& Masithah, 2016). According to Susanti \& Putra (2019), the system used to calculate market returns is as follows:

$$
\mathrm{Rm}=\frac{\mathrm{IHSG}_{\mathrm{t}}-\mathrm{IHSG}_{\mathrm{t}-1}}{\mathrm{IHSG}_{\mathrm{t}-1}}
$$

Where $\mathrm{Rm}$ is Market rate of return, and IHSG is duration for stock charge index $\mathrm{t}$ then IHSGt1 is stock price index length $\mathrm{t}-1$. Beside that in evaluation return of stock, ought to be calculate hazard free. Risk free is an analysis to calculate the safe fee of return. The information used in this Risk free calculation is Bank Indonesia Certification (Susanti \& Putra, 2019). After analysis return market, the subsequent step for calculate anticipated return of persona is calculate sytematic risk. According to Siti \& Yaya (2018) one way to calculate systematic threat is to use beta analysis. Beta comparison is a system of examining the movement of the price of returns in a protection or can also be said as an evaluation of the fee of market returns. According Susanti \& Putra (2019), the components used in calculating the fee of the Stock Beta is :

$$
\beta_{\mathrm{i}}=\frac{\sigma \mathrm{im}}{\sigma^{2} \mathrm{~m}}
$$

Where $\beta I$ is stock beta and oimis covariance return market also $\sigma^{2} m$ is variance market. After examining person returns, market returns, chance free and beta values on stocks, it is continued by means of examining expected returns. Expected return (expected return) is one of the analyzes aimed at making policies in investing.

The anticipated investment return evaluation has very essential function compared to different funding analyzes (Alifiani, 2017). According to Susanti \& Putra (2019), this anticipated rate of return analysis can also make a calculation between hazard and predicted investment consist of predicted returns person $[(\mathrm{Ri})]$, risk free $(\mathrm{Rf})$, beta $(\beta)$ and expected return market $[\mathrm{E}(\mathrm{Rm})]$ can be make system as under :

$$
\mathrm{E}(\mathrm{Ri})=\mathrm{Rf}+\beta \mathrm{i}[\mathrm{E}(\mathrm{Rm})-\mathrm{Rf}]
$$

To illustrate the price of an individual's anticipated return, a Security Market Line plan is made the place this design illustrates the relationship between the cost of an individual's expected return and systematic chance (Beta). The analysis in the Security Market Line if the increased the beta fee of a stock, the expected return on funding will be even larger (Jylh ̈̈, 2018). 


\section{RESULT AND DISCUSSION}

Profit in shares which is regularly referred to as dividends as a form of income sharing for shareholders is one structure of individual stock returns. Monthly closing fee information on shares is used to analyze the person returns of each LQ45 enterprise stock. Based on an analysis of 30 company shares that are labeled into LQ45 produces statistics on individual stock returns as follows:

Table 3. Return Individual Company Stock Returns LQ45 from 2017-2019

\begin{tabular}{|c|c|c|c|}
\hline No. & Stock Code & Company Name & $\begin{array}{c}\text { Return } \\
\text { Individual } \\
\text { (Ri) }\end{array}$ \\
\hline 1. & ADRO & PT. Adaro Energy Tbk & $0,30 \%$ \\
\hline 2. & AKRA & PT. AKR Corporindo Tbk & $0,29 \%$ \\
\hline 3. & ANTM & PT. Aneka Tambang Tbk & $-0,30 \%$ \\
\hline 4. & ASII & PT. Astra International Tbk & $-0,24 \%$ \\
\hline 5. & BBCA & PT. Bank Central Asia Tbk & $2,27 \%$ \\
\hline 6. & BBNI & PT. Bank Negara Indonesia Tbk & $1,19 \%$ \\
\hline 7. & BBRI & PT. Bank Rakyat Indonesia Tbk & $1,92 \%$ \\
\hline 8. & BBTN & PT. Bank Tabungan Negara Tbk & $0,86 \%$ \\
\hline 9. & BMRI & PT. Bank Mandiri Tbk & $1,06 \%$ \\
\hline 10. & BRPT & PT. Barito Pacific Tbk & $0,30 \%$ \\
\hline 11. & BSDE & PT. Bumi Serpong Damai Tbk & $0,29 \%$ \\
\hline 12. & EXCL & PT. XL Axiata Tbk. & $-0,30 \%$ \\
\hline 13. & GGRM & PT. Gudang Garam Tbk. & $-0,24 \%$ \\
\hline 14. & HMSP & PT. Hanjaya Mandala Sampoerna Tbk & $2,27 \%$ \\
\hline 15. & ICBP & PT. Indofood CBP Sukses Makmur Tbk & $1,19 \%$ \\
\hline 16. & INCO & PT. Vale Indonesia Tbk & $1,92 \%$ \\
\hline 17. & INDF & PT. Indofood Sukses Makmur Tbk & $0,86 \%$ \\
\hline 18. & INTP & PT. Indocement Tunggal Prakarsa Tbk & $1,06 \%$ \\
\hline 19. & JSMR & PT. Jasa Marga (Persero) Tbk & $2,12 \%$ \\
\hline 20. & KLBF & PT. Kalbe Farma Tbk. & $0,15 \%$ \\
\hline 21. & LPPF & PT. Matahari Department Store Tbk & $1,26 \%$ \\
\hline 22. & $\mathrm{MNCN}$ & PT. Media Nusantara Citra Tbk & $0,86 \%$ \\
\hline 23. & PGAS & PT. Perusahaan Gas Negara Tbk & $0,46 \%$ \\
\hline 24. & PTBA & PT. Bukit Asam Tbk & $-2,57 \%$ \\
\hline 25. & PTPP & PT. PP (Persero) Tbk & $0,80 \%$ \\
\hline 26. & SCMA & PT. Surya Citra Media Tbk & $0,00 \%$ \\
\hline 27. & SMGR & PT. Semen Indonesia (Persero) Tbk & $0,99 \%$ \\
\hline 28. & SRIL & PT. Sri Rejeki Isman Tbk & $0,70 \%$ \\
\hline 29. & TLKM & PT. Telekomunikasi Indonesia Tbk & $0,21 \%$ \\
\hline 30. & UNTR & PT. United Tractors Tbk & $0,25 \%$ \\
\hline
\end{tabular}

Source : Data Processed, 2020 
In Table 3, LQ45 Company's Individual Stock Returns in 2017-2019, it can be seen that the enterprise with the very best stock return is PT Barito Pacific Tbk (BRPT), with a Ri price of $23.99 \%$ and the lowest stock return is located at the Matahari Department Store (LPPF), which is $-2.57 \%$. The effects of this learn about differed performed by using Susanti \& Putra (2019) where the consequences of LQ45 organization lookup from 20122016 bought had been the highest stock return value held via Indofood Sukses Makmur, Tbk (ICBP) with a Ri value of $3.18 \%$ and a value of The lowest stock return is held by using Semen Indonesia (Persero) Tbk (SMGR) of $-1.1 \%$. For the evaluation of calculations of market returns, the source of the statistics used is the Composite Stock Index (CSPI) data. The Composite Stock Index is used because it is capable to signify the whole trading things to do of shares contained in the Indonesia Stock Exchange (IDX).

Table 4. Market Returns (IHSG) for 2017-2019

\begin{tabular}{|c|c|c|c|c|c|c|}
\hline Month & IHSG & Return & No. & Month & IHSG & Return \\
\hline 1. January 2017 & $6.299,54$ & $36,50 \%$ & 19. & July 2018 & $5.799,24$ & $-2,31 \%$ \\
\hline $\begin{array}{ll}2 . & \text { February } 2017\end{array}$ & $6.011,83$ & $-4,57 \%$ & 20. & Agust 2018 & $5.983,59$ & $3,18 \%$ \\
\hline 3. $\quad$ March 2017 & $6.228,32$ & $3,60 \%$ & 21. & September 2018 & $5.994,60$ & $0,18 \%$ \\
\hline 4. $\quad$ April 2017 & $6.169,10$ & $-0,95 \%$ & 22. & October 2018 & $6.188,99$ & $3,24 \%$ \\
\hline $\begin{array}{ll}\text { 5. } & \text { May } 2017\end{array}$ & $6.328,47$ & $2,58 \%$ & 23. & November 2018 & $6.597,22$ & $6,60 \%$ \\
\hline 6. $\quad$ June 2017 & $6.390,50$ & $0,98 \%$ & 24. & December 2018 & $6.605,63$ & $0,13 \%$ \\
\hline 7. $\quad$ July 2017 & $6.358,63$ & $-0,50 \%$ & 25. & January 2019 & $6.355,65$ & $-3,78 \%$ \\
\hline $\begin{array}{ll}\text { 8. } & \text { August } 2017\end{array}$ & $6.209,12$ & $-2,35 \%$ & 26. & February 2019 & $5.952,14$ & $-6,35 \%$ \\
\hline 9. $\quad$ September 2017 & $6.455,35$ & $3,97 \%$ & 27. & March 2019 & $6.005,78$ & $0,90 \%$ \\
\hline 10. $\quad$ October 2017 & $6.468,75$ & $0,21 \%$ & 28. & April 2019 & $5.900,85$ & $-1,75 \%$ \\
\hline 11. November 2017 & $6.443,35$ & $-0,39 \%$ & 29. & May 2019 & $5.864,06$ & $-0,62 \%$ \\
\hline 12. $\quad$ December 2017 & $6.532,97$ & $1,39 \%$ & 30. & June 2019 & $5.840,94$ & $-0,39 \%$ \\
\hline 13. January 2018 & $6.194,50$ & $-5,18 \%$ & 31. & July 2019 & $5.829,71$ & $-0,19 \%$ \\
\hline 14. February 2018 & $6.056,12$ & $-2,23 \%$ & 32. & Agust 2019 & $5.738,15$ & $-1,57 \%$ \\
\hline 15. March 2018 & $5.831,65$ & $-3,71 \%$ & 33. & September 2019 & $5.685,30$ & $-0,92 \%$ \\
\hline 16. $\quad$ April 2018 & $5.976,55$ & $2,48 \%$ & 34. & October 2019 & $5.568,11$ & $-2,06 \%$ \\
\hline 17. May 2018 & $6.018,46$ & $0,70 \%$ & 35. & November 2019 & $5.386,69$ & $-3,26 \%$ \\
\hline 18. June 2018 & $5.936,44$ & $-1,36 \%$ & 36. & December 2019 & $5.294,10$ & $-1,72 \%$ \\
\hline Total & $20,47 \%$ & & & & Maximum & $36,50 \%$ \\
\hline $\mathrm{E}(\mathrm{Rm})$ & $-5,79 \%$ & & & & Minimum & $-6,35 \%$ \\
\hline
\end{tabular}

Source : Data Processed, 2020

Table 4 explains, the LQ45 Company's Market Return from 2017-2019 which can be analyzed that the average market return $(\mathrm{Rm})$ is $-5,79 \%$. From the evaluation it can additionally be explained that in February 2019 it has the lowest market price of return of $-6,35 \%$ so that it can be defined that in that month IHSG trading skilled an unfavourable state of affairs for investors. Different from January 2017 from the desk information above the very best market return is $36,50 \%$, this ocurs because there is a very big soar from the CSPI where in December 2016, the CSPI used to be 4.615,16 whilst in January 2017 the CSPI was 6.299,54 so that in January 2017 the JCI return fee was 36,50\%. This should imply JCI index skilled a favorable state of affairs for investors. The outcome acquired in desk 4 vary from results of research performed through Susanti \& Putra (2019) the place the outcome of lookup on LQ45 corporations from 2012-2016 get a market return of $1 \%$. For records sources from risk free returns sourced from Bank Indonesia hobby rates. The risk free (Rf) degree outcomes are as follows: 
Table 5. Risk Free (Rf) level results from 2017-2019

\begin{tabular}{|c|c|c|c|c|}
\hline No. & Month & In 2017 & In 2018 & In 2019 \\
\hline 1. & January & $4,75 \%$ & $4,25 \%$ & $6,00 \%$ \\
\hline 2. & February & $4,75 \%$ & $4,25 \%$ & $6,00 \%$ \\
\hline 3. & March & $4,75 \%$ & $4,25 \%$ & $6,00 \%$ \\
\hline 4. & April & $4,75 \%$ & $4,25 \%$ & $6,00 \%$ \\
\hline 5. & May & $4,75 \%$ & $4,50 \%$ & $6,00 \%$ \\
\hline 6. & June & $4,75 \%$ & $5,25 \%$ & $6,00 \%$ \\
\hline 7. & July & $4,75 \%$ & $5,25 \%$ & $5,75 \%$ \\
\hline 8. & Agust & $4,50 \%$ & $5,50 \%$ & $5,50 \%$ \\
\hline 9. & September & $4,25 \%$ & $5,75 \%$ & $5,25 \%$ \\
\hline & October & $4,25 \%$ & $5,75 \%$ & $5,00 \%$ \\
\hline 11. & November & $4,25 \%$ & $6,00 \%$ & $5,00 \%$ \\
\hline 12. & December & $4,25 \%$ & $6,00 \%$ & $5,00 \%$ \\
\hline \multicolumn{2}{|c|}{ Average } & $4,56 \%$ & $5,08 \%$ & $5,63 \%$ \\
\hline \multicolumn{2}{|c|}{ Average in 3 Years } & \multicolumn{3}{|c|}{$5,09 \%$} \\
\hline \multicolumn{2}{|c|}{ Maxsimum } & \multicolumn{3}{|c|}{$6,00 \%$} \\
\hline \multicolumn{2}{|c|}{ Minimum } & \multicolumn{3}{|c|}{$4,25 \%$} \\
\hline
\end{tabular}

Source : Data Processed, 2020

In table 5 above, the Rf calculation effects from 2017-2019 can be viewed that the average cost of risk free from 2017-2019 is 5,09\% with the absolute best hazard free rate of 6,00\% and the lowest of $4,25 \%$. This result is distinctive from lookup conducted via Susanti \& Putra (2019) the place for 2012-2016 the threat free value is 6,66\%. Systematic chance is a chance held by using shares which is regularly referred to as Beta $(\beta \mathrm{i})$. The relationship between the charge of return of a stock with the price of market return will be seen by calculating the inventory beta. The data on the systematic chance analysis of 30 organisation shares in this study is sourced from Yahoo Finance data, namely:

Table 6. Results of the calculation of Systematic Risk of Individual Stocks ( $\beta \mathrm{i}$ )

\begin{tabular}{cllc}
\hline No. & Code Stock & \multicolumn{1}{c}{ Company Name } & Beta \\
\hline 1. & ADRO & PT. Adaro Energy Tbk & 1,26 \\
\hline 2. & AKRA & PT. AKR Corporindo Tbk & 0,43 \\
\hline 3. & ANTM & PT. Aneka Tambang Tbk & 1,16 \\
\hline 4. & ASII & PT. Astra International Tbk & 0,44 \\
\hline 5. & BBCA & PT. Bank Central Asia Tbk & 0,34 \\
\hline 6. & BBNI & PT. Bank Negara Indonesia Tbk & 0,70 \\
\hline 7. & BBRI & PT. Bank Rakyat Indonesia Tbk & 0,57 \\
\hline 8. & BBTN & PT. Bank Tabungan Negara Tbk & 0,82 \\
\hline 9. & BMRI & PT. Bank Mandiri Tbk & 0,49 \\
\hline 10. & BRPT & PT. Barito Pacific Tbk & 1,16 \\
\hline 11. & BSDE & PT. Bumi Serpong Damai Tbk & 0,80 \\
\hline 12. & EXCL & PT. XL Axiata Tbk. & 0,28 \\
\hline 13. & GGRM & PT. Gudang Garam Tbk. & 0,20 \\
\hline 14. & HMSP & PT. Hanjaya Mandala Sampoerna Tbk & 0,20 \\
\hline 15. & ICBP & PT. Indofood CBP Sukses Makmur Tbk & $-0,08$ \\
\hline 16. & INCO & PT. Vale Indonesia Tbk & 1,49 \\
\hline
\end{tabular}




\begin{tabular}{cllc}
\hline 17. & INDF & PT. Indofood Sukses Makmur Tbk & 0,30 \\
\hline 18. & INTP & PT. Indocement Tunggal Prakarsa Tbk & 0,56 \\
\hline 19. & JSMR & PT. Jasa Marga (Persero) Tbk & 0,39 \\
\hline 20. & KLBF & PT. Kalbe Farma Tbk. & 0,62 \\
\hline 21. & LPPF & PT. Matahari Department Store Tbk & 0,72 \\
\hline 22. & MNCN & PT. Media Nusantara Citra Tbk & 1,10 \\
\hline 23. & PGAS & PT. Perusahaan Gas Negara Tbk & 1,28 \\
\hline 24. & PTBA & PT. Bukit Asam Tbk & 1,39 \\
\hline 25. & PTPP & PT. PP (Persero) Tbk & 1,31 \\
\hline 26. & SCMA & PT. Surya Citra Media Tbk & 0,75 \\
\hline 27. & SMGR & PT. Semen Indonesia (Persero) Tbk & 0,79 \\
\hline 28. & SRIL & PT. Sri Rejeki Isman Tbk & 0,56 \\
\hline 29. & TLKM & PT. Telekomunikasi Indonesia Tbk & $-0,13$ \\
\hline 30. & UNTR & PT. United Tractors Tbk & 0,63 \\
\hline
\end{tabular}

Source : Data Processed, 2020

From the table in 6 , it can be viewed the consequences of the systematic risk calculation of stocks which indicates an common cost of $\beta \mathrm{i}$ of 0,69 which potential that universal business enterprise shares that are grouped into LQ45 have little systematic danger and are no longer too sensitive in responding to changes in market costs. This is extra is extraordinary from lookup carried out by way of Susanti \& Putra (2019) the place the consequences of the beta value of shares received amounted to 0,1410577. After evaluation of calculation of Systematic Risk of Individual Stocks, the subsequent step is calculate Expected Return of Individual $[\mathrm{E}(\mathrm{Ri})]$. The degree of profits to be anticipated via buyers from stock investments made is regularly known with the aid of the identify of the anticipated rate of return [E(Ri)]. The outcomes of the $[\mathrm{E}(\mathrm{Ri})]$ calculation are as follows:

Table 7. The calculation results $[\mathrm{E}(\mathrm{Ri})]$

\begin{tabular}{cllllc}
\hline No. & Code Stock & $\begin{array}{c}\mathrm{E}(\mathrm{Ri}) \\
\text { CAPM }\end{array}$ & No. & Code Stock & $\begin{array}{c}\mathrm{E}(\mathrm{Ri}) \\
\mathrm{CAPM}\end{array}$ \\
\hline 1. & ADRO & $-8,62 \%$ & 16. & INCO & $-11,12 \%$ \\
\hline 2. & AKRA & $0,41 \%$ & 17. & INDF & $1,83 \%$ \\
\hline 3. & ANTM & $-7,53 \%$ & 18. & INTP & $-1,00 \%$ \\
\hline 4. & ASII & $0,30 \%$ & 19. & JSMR & $0,85 \%$ \\
\hline 5. & BBCA & $1,39 \%$ & 20. & KLBF & $-1,65 \%$ \\
\hline 6. & BBNI & $-2,52 \%$ & 21. & LPPF & $-2,74 \%$ \\
\hline 7. & BBRI & $-1,11 \%$ & 22. & MNCN & $-6,88 \%$ \\
\hline 8. & BBTN & $-3,83 \%$ & 23. & PGAS & $-8,83 \%$ \\
\hline 9. & BMRI & $-0,24 \%$ & 24. & PTBA & $-10,03 \%$ \\
\hline 10. & BRPT & $-7,53 \%$ & 25. & PTPP & $-9,16 \%$ \\
\hline 11. & BSDE & $-3,61 \%$ & 26. & SCMA & $-3,07 \%$ \\
\hline 12. & EXCL & $2,04 \%$ & 27. & SMGR & $-3,50 \%$ \\
\hline 13. & GGRM & $2,91 \%$ & 28. & SRIL & $-1,00 \%$ \\
\hline 14. & HMSP & $2,91 \%$ & 29. & TLKM & $6,50 \%$ \\
\hline 15. & ICBP & $5,96 \%$ & 30. & UNTR & $-1,76 \%$ \\
\hline So & & & &
\end{tabular}

Source : Data Processed, 2020 
From the records in table 5, it is defined that traders who assume the absolute best predicted return of $[\mathrm{E}(\mathrm{Ri})]$ are $6,50 \%$, particularly TLKM and the business enterprise with the lowest expected return $[\mathrm{E}(\mathrm{Ri})]$ is INCO of $-11,12 \%$. The consequences of this study differed through Susanti \& Putra (2019) on the [E (Ri)] fee of LQ45 companies from 2012-2016 the place the results received had been the easiest [E (Ri)] values, particularly the Alam Sutera Realty Tbk business enterprise with a cost of $1,16 \%$ and for businesses with the lowest [E (Ri)] value, namely Indofood CBP Sukses Makmur Tbk at $0,02 \%$.

To illustrate the CAPM model, a Security Market Line chart or often recognised as SML was made. The relationship between systematic threat or beta $(\beta)$ and expeceted return is illustrated graphically as follows:

Figure 1 : Security Market Line (SML) Graphic

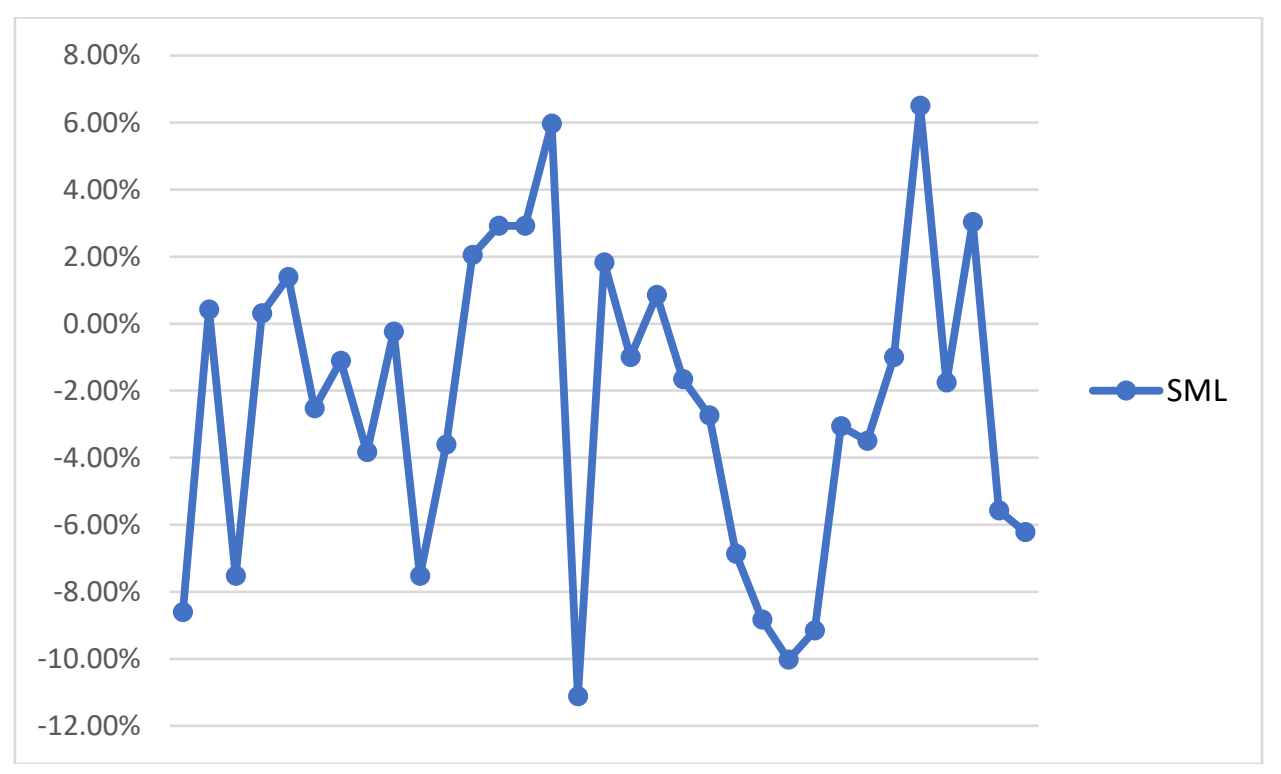

Source : Data Processed, 2020

After analysis Expected Return of Individual and make Security Market Line Graphic, the next step for analysis is stock clasification. Stock classification can be devided come to be two is efficient stock and inefficient stock. From the evaluation described above, the shares classified as environment friendly and inefficient stocks are as follows:

Table 8. Classification Stock in Indeks LQ45

\begin{tabular}{clccl}
\hline No. & Code Stock & Ri & $\begin{array}{c}\text { E(Ri) } \\
\text { CAPM }\end{array}$ & Category \\
\hline 1 & ADRO & $0,30 \%$ & $-8,62 \%$ & Efficient \\
\hline 2 & AKRA & $0,29 \%$ & $0,41 \%$ & Inefficient \\
\hline 3 & ANTM & $-0,30 \%$ & $-7,53 \%$ & Efficient \\
\hline 4 & ASII & $-0,24 \%$ & $0,30 \%$ & Inefficient \\
\hline 5 & BBCA & $2,27 \%$ & $1,39 \%$ & Efficient \\
\hline 6 & BBNI & $1,19 \%$ & $-2,52 \%$ & Efficient \\
\hline 7 & BBRI & $1,92 \%$ & $-1,11 \%$ & Efficient \\
\hline 8 & BBTN & $0,86 \%$ & $-3,83 \%$ & Efficient \\
\hline 9 & BMRI & $1,06 \%$ & $-0,24 \%$ & Efficient \\
\hline 10 & BRPT & $23,99 \%$ & $-7,53 \%$ & Efficient \\
\hline 11 & BSDE & $-0,81 \%$ & $-3,61 \%$ & Efficient \\
\hline
\end{tabular}




\begin{tabular}{llccl}
\hline 12 & EXCL & $0,66 \%$ & $2,04 \%$ & Inefficient \\
\hline 13 & GGRM & $-0,15 \%$ & $2,91 \%$ & Inefficient \\
\hline 14 & HMSP & $-1,44 \%$ & $2,91 \%$ & Inefficient \\
\hline 15 & ICBP & $0,89 \%$ & $5,96 \%$ & Inefficient \\
\hline 16 & INCO & $2,12 \%$ & $-11,12 \%$ & Efficient \\
\hline 17 & INDF & $0,15 \%$ & $1,83 \%$ & Inefficient \\
\hline 18 & INTP & $1,26 \%$ & $-1,00 \%$ & Efficient \\
\hline 19 & JSMR & $0,86 \%$ & $0,85 \%$ & Efficient \\
\hline 20 & KLBF & $0,46 \%$ & $-1,65 \%$ & Efficient \\
\hline 21 & LPPF & $-2,57 \%$ & $-2,74 \%$ & Efficient \\
\hline 22 & MNCN & $0,80 \%$ & $-6,88 \%$ & Efficient \\
\hline 23 & PGAS & $0,00 \%$ & $-8,83 \%$ & Efficient \\
\hline 24 & PTBA & $0,99 \%$ & $-10,03 \%$ & Efficient \\
\hline 25 & PTPP & $-1,26 \%$ & $-9,16 \%$ & Efficient \\
\hline 26 & SCMA & $-1,50 \%$ & $-3,07 \%$ & Efficient \\
\hline 27 & SMGR & $1,31 \%$ & $-3,50 \%$ & Efficient \\
\hline 28 & SRIL & $0,70 \%$ & $-1,00 \%$ & Efficient \\
\hline 29 & TLKM & $0,21 \%$ & $6,50 \%$ & Inefficient \\
\hline 30 & UNTR & $0,25 \%$ & $-1,76 \%$ & Efficient \\
\hline
\end{tabular}

Source : Data Processed, 2020

From the records in table 8, it can be explained that the outcomes of classifying LQ45 shares in which there are 22 LQ45 groups whose shares are labeled as environment friendly and the ultimate 8 businesses whose shares can be grouped into inefficient shares. As for numerous factors that decide grouping, through evaluating between $\mathrm{Ri}$ and $\mathrm{E}$ ( $\mathrm{Ri}$ ), if $\mathrm{Ri}$ > $\mathrm{E}$ (Ri) then the shares will be grouped into environment friendly shares, but conversely if $\mathrm{Ri}$ no longer efficient. And if the outcomes of the $\mathrm{E}$ (Ri) evaluation exhibit that the stock is efficient, then the stock ought to be offered and used as an investment portfolio. This is distinct from research carried out by Susanti \& Putra (2019) where from the results of an analysis of 20 LQ45 groups from 2012-2016 classified as environment friendly shares by 10 agencies and the remaining 10 groups are grouped into inefficient shares.

\section{CONCLUSION}

The conclusions of this study include:

1. For individual returns in the LQ45 stock group from 2017 to 2019, it consists of shares with the highest return held by PT. Barito Pacific Tbk of $23.99 \%$, while the lowest rate of return held by PT. Matahari Department Store Tbk by $-2.57 \%$.

2. The level of positive stock returns for the LQ45 stock group from 2017 to 2019 , namely shares with the code ADRO, AKRA, BBCA, BBNI, BBRI, BBTN, BMRI, BRPT, EXCL, ICBP, INCO, INDF, INTP, JSMR, KLBF, MNCN, PGAS, PTBA, SMGR, SRIL, TLKM, UNTR, while stocks that have a negative return value for the LQ45 stock group from 2017 to 2019 include ANTM, ASII, BSDE, GGRM, HMSP, LPPF, PTPP and SCMA.

3. The highest Composite Stock Price Index (CSPI) from 2017 to 2019 is $6,605.63$ and the lowest Composite Stock Price Index (CSPI) from 2017 to 2019 is 5,294.10. Whereas the highest rate of return on IHSG from 2017 to 2019 was $36.50 \%$ and the lowest return rate of IHSG from 2017 to 2019 was $-6.35 \%$.

4. The Risk Free (Rf) level is taken from the interest rate of Bank Indonesia Certificates from 2017 to 2019. The highest SBI interest rate occurs in January to June 2019 at $6 \%$ while the 
lowest SBI interest rate occurs in September 2017 to month April 2018 amounted to $4.25 \%$.

5. Beta value for each share in this study is taken from yahoo finance data where the highest beta value is held by the company PT. Vale Indonesia Tbk (INCO) with a value of 1.49 and the lowest beta value held by the company PT. Telecommunications Indonesia Indonesia. (TLKM) with a value of -0.13 .

6. The highest level of $\mathrm{E}(\mathrm{Ri})$ value is held by the company PT. Telecommunications Indonesia Indonesia. (TLKM) of $6.50 \%$ and the lowest $\mathrm{E}(\mathrm{Ri})$ value held by the company PT. Vale Indonesia Tbk (INCO) of $-11.12 \%$.

7. Efficient shares are shares of companies that are worth buying into stock portfolios. The provisions of an efficient stock that is if the value of $\mathrm{Ri}>\mathrm{E}$ (Ri). From this formula, efficient stocks are companies that have ADRO, ANTM, BBCA, BBNI, BBRI, BBTN, BMRI, BRPT, BSDE, INCO, INTP, JSMR, KLBF, LPPF, MNCN, PGAS, PTBA, PTPPP , SCMA, SMGR, SRIL, UNTR, WIKA, WSKT.

8. While inefficient shares are shares of companies that are not eligible to be purchased to be used as stock portfolios. The uncertainty of stock is that is if the value of Ri $<\mathrm{E}$ (Ri). From this formulation, the inefficient shares are company shares that have AKRA, ASII, EXCL, GGRM, HMSP, ICBP, INDF, TLKM and UNVR codes.

\section{REFERENCE}

Adisetiawan, R. (2017). Globalisasi Pasar Modal Dunia Dan Pengaruhnya Terhadap Pasar Modal Indonesia. Ekonomis : Journal of Economics and Business, 1(1), 10-17. https://doi.org/10.33087/ekonomis.v1i1.19

Alifiani, M. A. (2017). Analisis Return dan Risk atas Investasi Saham pada Perusahaan Otomotif dan Komponen Go Publik di Bursa Efek Indonesia Periode 2014-2016. Jurnal Studi Manajemen Bisnis, $\quad 1(1), \quad 1-9$. https://jurnal.umk.ac.id/index.php/jsmb/article/view/3760

Ditha Indah, F., R. Deni Muhammad, D., \& Nor, N. (2019). Analisis Capital Asset Pricing Model ( Capm ) Dalam Pengambilan Keputusan. Jurnal Ekonomi Dan Bisnis, 20(2), 11-18. https://doi.org/http://dx.doi.org/10.30659/ekobis.20.2.11-18

Jylh ̈̈, P. (2018). Margin Requirements and the Security Market Line. Journal of Finance, 73(3), 1281-1321. https://doi.org/10.1111/jofi.12616

Liani, M. (2017). Analysis of the Comparison Among Efficient Stocks That Form Portfolio Using Capital Asset Pricing Model (CAPM) and Fama-French Three Factor Model (Case Study on Kompas 100 Companies From 2013-2015). Jurnal Akuntansi, Kewirausahaan Dan Bisnis, 2(1), 76-89. http://www.ejournal.pelitaindonesia.ac.id/ojs32/index.php/KURS/article/view/229

Ni Wayan Sri, A., \& Masithah, A. (2016). Analisis Pengaruh Inflasi, Suku Bunga, Nilai Tukar (Kurs) dan Pertumbuhan Produk Domestik Bruto (PDB) Terhadap Indeks Harga Saham Gabungan (IHSG) Studi Kasus pada Perusahaan Properti yang terdaftar di Bursa Efek Indonesia. Jurnal Manajemen Dan Akuntansi, 17(1), 43-52. http://journal.stieikayutangi-bjm.ac.id/index.php/jma/article/view/269

Riska, Y., Topowijono, \& Devi Farah, A. (2014). Penerapan Metode Capm (Capital Asset Pricing Model) Untuk Menentukan Pilihan Investasi Pada Saham (Studi Pada Perusahaan Sektor Consumer Good Industry di Bursa Efek Indonesia Periode 20102012). Jurnal Administrasi Bisnis, 13(2), 122-130. http://administrasibisnis.studentjournal.ub.ac.id/

Siti, M., \& Yaya, S. (2018). Faktor-faktor Fundamental yang berpengaruh terhadap Beta Saham (Studi Kasus Perusahaan Finance yang terdaftar di Bursa Efek Indonesia Periode 2013-2016). The Journal of Business and Management Research, 1(2), 127-132. 
http://jurnal.uniyap.ac.id/index.php/pasca/article/view/459

Susanti, N., \& Putra, O. E. (2019). Penerapan Asset Pricing Model (Capm) Terhadap Keputusan Investasi Pada Indeks Lq 45 Periode 2012-2016. Jurnal Muara Ilmu Ekonomi Dan Bisnis, 2(2), 369-379. https://doi.org/10.24912/jmieb.v2i2.1556

Wildan Deny, S., Suhadak, \& Devi Farah, A. (2015). Penggunaan Metode Capital Asset Pricing Model (CAPM) dalam menentukan Saham Efisien (Studi pada Saham-Saham Perusahaan yang terdaftar di Indeks Kompas100 Periode 2010-2013). Jurnal Administrasi Bisnis, 25(1), $1-7$. http://administrasibisnis.studentjournal.ub.ac.id/index.php/jab/article/view/971 